\title{
Erratum to: 'Draft genome sequence of Bacillus azotoformans MEV2011, a (Co-) denitrifying strain unable to grow with oxygen'
}

Maja Nielsen ${ }^{1 \dagger}$, Lars Schreiber ${ }^{2+}$, Kai Finster ${ }^{1,3}$ and Andreas Schramm ${ }^{1,2^{*}}$

Unfortunately, the original version of this article [1] contained an error. The citation details was included incorrectly as 9:23. The correct citation is 10:4.

\section{Author details}

${ }^{1}$ Section for Microbiology, Department of Bioscience, Aarhus University, Aarhus, Denmark. ${ }^{2}$ Center for Geomicrobiology, Department of Bioscience, Aarhus University, Aarhus, Denmark. ${ }^{3}$ Stellar Astrophysics Centre, Department of Physics and Astronomy, Aarhus University, Aarhus, Denmark.

Received: 17 August 2015 Accepted: 17 August 2015

Published online: 30 September 2015

\section{Reference}

1. Nielsen M, Schreiber L, Finster K, Schramm A. Draft genome sequence of Bacillus azotoformans MEV2011, a (Co-) denitrifying strain unable to grow with oxygen. Stand Genomic Sci. 2015;10:4.

\footnotetext{
* Correspondence: andreas.schramm@biology.au.dk

${ }^{\dagger}$ Equal contributors

${ }^{1}$ Section for Microbiology, Department of Bioscience, Aarhus University, Aarhus, Denmark

${ }^{2}$ Center for Geomicrobiology, Department of Bioscience, Aarhus University,

Aarhus, Denmark

Full list of author information is available at the end of the article
}

Submit your next manuscript to BioMed Central and take full advantage of:

- Convenient online submission

- Thorough peer review

- No space constraints or color figure charges

- Immediate publication on acceptance

- Inclusion in PubMed, CAS, Scopus and Google Scholar

- Research which is freely available for redistribution

\section{Biomed Central}

(c) 2015 Nielsen et al. Open Access This article is distributed under the terms of the Creative Commons Attribution 4.0 International License (http://creativecommons.org/licenses/by/4.0/), which permits unrestricted use, distribution, and reproduction in any medium, provided you give appropriate credit to the original author(s) and the source, provide a link to the Creative Commons license, and indicate if changes were made. The Creative Commons Public Domain Dedication waiver (http://creativecommons.org/publicdomain/zero/1.0/) applies to the data made available in this article, unless otherwise stated. 